\title{
INTELLECTUAL RETURNEES AS DRIVERS OF INDIGENOUS INNOVATION: EVIDENCE FROM THE CHINESE PHOTOVOLTAIC INDUSTRY
}

\author{
Siping Luo \\ Mary E. Lovely \\ David Popp \\ Working Paper 19518 \\ http://www.nber.org/papers/w19518 \\ NATIONAL BUREAU OF ECONOMIC RESEARCH \\ 1050 Massachusetts Avenue \\ Cambridge, MA 02138 \\ October 2013
}

The views expressed herein are those of the authors and do not necessarily reflect the views of the National Bureau of Economic Research.

NBER working papers are circulated for discussion and comment purposes. They have not been peerreviewed or been subject to the review by the NBER Board of Directors that accompanies official NBER publications.

(C) 2013 by Siping Luo, Mary E. Lovely, and David Popp. All rights reserved. Short sections of text, not to exceed two paragraphs, may be quoted without explicit permission provided that full credit, including (C) notice, is given to the source. 
Intellectual Returnees as Drivers of Indigenous Innovation: Evidence from the Chinese Photovoltaic Industry Siping Luo, Mary E. Lovely, and David Popp

NBER Working Paper No. 19518

October 2013

JEL No. O30,O31,O32,Q42,Q55

\begin{abstract}
We offer new evidence on indigenous innovation and intellectual returnees by estimating the relationship between patenting by Chinese photovoltaic firms and the presence of corporate leaders with international experience. Our research approach combines data from three sources: the industrial census, international and domestic patent records, and leadership biographical information. Using nonlinear methods, we find robust evidence that returnees positively influence patenting activity and also promote neighboring firm innovation. We find no tendency for export intensive firms to patent more. Controlling for R\&D expenditures, we find that firms with returnees in leadership roles have more patents.
\end{abstract}

Siping Luo

School of Public Policy and Management

Tsinghua University

Beijing, China 100084

luosiping@gmail.com

Mary E. Lovely

Syracuse University

Maxwell School of Citizenship and Public Affairs

Department of Economics

110 Eggers

Syracuse, NY 13244

melovely@maxwell.syr.edu
David Popp

Department of Public Administration

and International Affairs

Syracuse University

The Maxwell School

426 Eggers Hall

Syracuse, NY 13244-1020

and NBER

dcpopp@maxwell.syr.edu 


\section{Introduction}

Innovation is seen as the driving force of productivity growth (Freeman and Soete, 1997; Freeman and Louca, 2001; Fagerberg and Verspagen, 2002). However, as shown by Breznitz and Murphree (2011) for the case of China, breakthrough innovation is not the only route to sustained growth. China has maintained steady income advances by receiving new technology from richer countries and mastering subsequent stages of innovation, a process known as “incremental innovation." Such innovation has helped to propel profound shifts in international flows of manufactured goods: the share of manufactures in the exports of developing countries has risen from 25 percent in 1980 to more than 80 percent today.

Empirical studies have identified various channels through which cross-border flows facilitate international technology transfer: international trade (e.g Keller, 2010), foreign direct investment (e.g. Veugelers and Cassiman, 2004; Kemeny, 2010), and joint R\&D ventures (e.g Zhou, et al., 2012)). ${ }^{2}$ Other scholars note the importance of supply chains to technology transfer, and especially to indigenous innovation. Xu and Sheng (2012) use firm-level evidence from China to argue that positive spillovers from FDI arise from forward linkages, that is, from access to superior intermediate inputs or capital equipment. Puga and Trefler (2010) expand the idea of forward linkages when they argue that the movement of new products from a developed to developing countries induces incremental indigenous innovation as the production process is refined and standardized in the low wage setting. This process of indigenous innovation allows low wage countries to export increasingly sophisticated new goods, thereby reducing the length

\footnotetext{
${ }^{1}$ Puga and Trefler (2010) attribute coinage of the term "incremental innovation" to Rosenberg (1982) and describe this form of invention as the "unsung hero of modern economic growth."

${ }^{2}$ Keller $(2004,2008)$ provides comprehensive surveys of the channels of international technology diffusion.
} 
of the product cycle and rapidly shifting world trade patterns. ${ }^{3}$

Recently, attention has shifted to "intellectual returnees," skilled persons who study or work in an advanced economy and subsequently return to their origin country, as the spark for indigenous innovation (Mountford, 1997; Kapur and McHale, 2005; Saxenian, 2006; Zucker and Darby, 2007). Returnees may offer their home countries human and venture capital, familiarity with systems developed by multinational firms, and valuable connections and cultural links to their host countries (Wang, Zweig, and Lin, 2011). Surprisingly given the frequency of stories about successful intellectual returnees in India and China, there is limited systematic evidence on the role played by cross-border skilled migrants to innovation within their country of origin.

This paper offers new evidence on the link between indigenous innovation and intellectual returnees by estimating the relationship between firm-level patenting in the photovoltaic (PV) industry and the presence of corporate leaders who have studied or trained in an advanced country. Our research approach requires the combination of data from three distinct sources. First, we use industrial census data to create a panel of more than 800 firms in the Chinese PV industry over the period 1998 to 2008. Secondly, we search Chinese and international patent office records to link each PV firm to its patenting activity. Lastly, we use firm, industry, and media reports to find the tertiary education and job experience of each firm's top management team in each year, identifying those who have studied or trained overseas.

Using nonlinear methods appropriate to count data, we test whether the presence of intellectual returnees in leadership positions within the firm leads to a higher likelihood of patenting. We find robust evidence that returnees do influence firm patenting activity and also

\footnotetext{
${ }^{3}$ Puga and Trefler (2010) provide a formal model of this process and supporting evidence of incremental innovation in low wage countries by combining data on the location of first production for innovative goods with data on patents by low wage country inventors for U.S. corporations.
} 
provide some benefits for innovating activity of neighboring firms via inter-firm spillovers. We find no tendency for firms with greater export intensity to patent more, nor do we find differences across firms based on age or size. Controlling for expenditures on R\&D activity, we still find that firms with intellectual returnees in leadership roles have more patents.

While we use a single country, China, and a single industry, photovoltaics, our study is clearly located within the domain of technology transfer for development. Fu, Pietrobelli, and Soete (2011) provide evidence from emerging economies that international technological diffusion can only occur with parallel indigenous efforts. Fu and Gong (2011) investigate this process in China and find that indigenous R\&D at the industry level is necessary for technology upgrading by domestic firms. At least some indigenous R\&D appears to be propelled by crossborder migration of skilled persons from technologically advanced countries. Song et al (2003) observe patenting by non-U.S. firms that hire engineers from U.S. firms and find that first patents granted to mobile engineers in the hiring firms are about seven times more likely to cite the source firm's patents than randomly selected controls. ${ }^{4}$

There is already a small body of evidence on intellectual returnees and innovation from China, which is not surprising given the scale of its economic activity and the importance the Chinese government has attached to the return of its high-skill, experienced citizens from overseas. Deng et al. (2012) draw on a firm-level World Bank survey of 998 Chinese manufacturing firms to estimate a positive relationship between the share of managers with an overseas education and a proxy for innovative performance, the share of new product exports in

\footnotetext{
${ }^{4}$ Along similar lines, Oettl and Agrwal (2008) find that cross-border movement of inventors raises patenting by the recruiting firm, but also leads to increased patent counts for the firm that lost the inventor and the source country.
} 
the firm's total export volume. ${ }^{5}$ Filatotchev et al. (2009) collect survey data from Beijing hightech firms and find that firms owned by Chinese natives with at least 2 years of commercial or educational experience in an OECD country are more likely to export and more likely to report export sales growth.

While this evidence suggests that intellectual returnees are a conduit for cross-border technology transfer, distinguishing causation from correlation is particularly difficult in this area of study due to limited availability of relevant data panel. Accounting for firm characteristics is vital, however, as there may be reverse causation running from innovation to returnees, with highly skilled overseas talent attracted only to those companies with strong innovative capacity. Filatotchev et al. (2011) recognize this issue and use Generalized Method of Moments (GMM) techniques to estimate a positive and significant relationship between non-returnee firms' patents per employee and the density of returnee-led firms in the same sector. Liu et al. (2010) also rely on GMM techniques in their study of the innovative performance of Chinese firms. They a positive and significant relationship between returnee-ownership status and the number of patents per employee. Neither of these studies is able to use fixed-effect techniques to estimate the relationship of interest because a founder's returnee status does not change over time.

Our analysis builds on these efforts by directly linking Chinese PV firms to their patent filings and testing the relationship between these innovative activities and the presence of returnees in the firm's leadership. Both our data collection and econometric methods are guided

\footnotetext{
${ }^{5}$ Other studies provide indirect support for a link between overseas experience and firm innovation. Notably, Lu et al. (2013) use a unique dataset of Chinese listed firms to investigate how domestic industrial diversification affects the number of foreign markets in which a firm operates, a proxy for technical sophistication. They find that international experience by the firm's top leaders strengthens the impact of domestic diversification on the extensive margin of firm's export markets.
} 
by a serious concern for identification. We focus on the firm's top management team rather than its founder so that firms' exposure to intellectual returnees varies over time. This broader focus then allows us to create a panel dataset and to use both negative binomial and Poisson fixedeffect estimation methods in our investigation.

We turn now to a discussion of China's photovoltaic industry and its innovative performance. In section 3, we present our research design and empirical implementation. Methods used in collecting and combining data on firms, patents, and returnees is described in section 4 and our empirical results are presented in section 5 . We discuss the challenges for continued technology transfer through cross-border migration in section 6 .

\section{China's photovoltaic industry and the patent explosion}

The Chinese PV industry, which has developed from virtual nonexistence to the world's third largest in less than a decade, is well suited to a study of returnees and incremental innovation. First, products along the silicon-based solar supply chain are highly standardized, eliminating complexity introduced by differences in product quality. Secondly, the industry relies on production technologies initially developed in industrialized countries, implying an initial transfer of advanced knowledge and equipment to China. Thirdly, and perhaps most importantly, significant complementary adaptation is needed all along the chain, and especially in upstream stages requiring advanced technologies and specific skills. Using detailed knowledge of the PV industry and extensive field interviews in China, de la Tour et al. (2011) conclude that, "a major part of the technology concerns the operation of manufacturing processes, which mainly consists of know-how. In the context, the manufacturing experience of skilled 
employees is a key asset." ${ }^{6}$ Lastly, there is evidence of a significant number of intellectual returnees in leadership roles in the industry (de la Tour et al., 2011; Luo and Yu, 2012). For these reasons, the PV industry is fertile ground for testing whether incremental innovation can be fueled by leaders familiar with overseas technologies and operations.

\section{Emergence of China's PV industry and intellectual returnees}

China's emergence as a major producer and exporter of photovoltaic equipment occurred rapidly. As seen in Figure 1, worldwide installation of new solar power generating capacity grew from a very small base in 2001 to almost 30 gigawatts installed in 2012. Within a decade, hundreds of Chinese PV firms participated in all segments of the PV supply chain, from silicon purification and wafer production to cell production and module assembly, leading to rapid declines in the installation price of solar equipment worldwide. Today, many of the largest and most visible firms in the industry, including Suntech, Trina, JingAo, and Yingli, are Chinese enterprises. $^{7}$

While exporting more than $95 \%$ of its production, China's share of global PV production rose from $1 \%$ in 2009 to $59 \%$ by $2010 .{ }^{8}$ It remains the world leader in cell production and module assembly, segments with relatively low technological barriers to entry and low industrial concentration. With strong support from the government, Chinese firms have rapidly increased their presence in upstream activities. Their capacity to purify silicon and produce ingots and

${ }^{6}$ de la Tour et al. (2011) use industry directories and field interviews to support their claim that Chinese producers acquired the skills and technology necessary to compete in this newly emergent sector through two main channels: imported capital equipment and the return of skilled individuals. They find a very limited role for technology transfer through multinational activity and none for licensing.

${ }^{7}$ A supply glut and heavy debt pushed Suntech Power Co. into bankruptcy court in March 2013. Suntech had been the world's largest manufacturer of solar panels but now faces an uncertain future (Ma and Glazer, 2013).

${ }^{8}$ Recently, China has moved strongly to increase domestic installed capacity. China was the top nonEuropean PV market in 2011, with 2.2 GW installed, followed by USA with 1.9 GW (EPIA, 2012). 
wafers, both of which require technologically advanced production processes, has allowed them to increase market share in these segments (de la Tour et al., 2011).

China's rapid entry into the global PV market has led to considerable trade friction. After failing to obtain significant countervailing duties on solar panel equipment imports from China, in 2012 the United State imposed anti-dumping duties of approximately $35 \%$ on billions of dollars of solar products to protect domestic manufacturers from lower-priced imports. In June 2013, the European Union imposed modest tariffs of 11.8 percent on solar panels imports worth five times as much as the American volume, but threatened to raise these rates if Beijing did not stop what the Europeans say is dumping. ${ }^{9}$ In July 2013 and in what many see as retaliation, China levied duties exceeding 50\% on solar-grade polysilicon imports from the United States, threatening to greatly reduce sales to the American polysilicon industry's largest customer. ${ }^{10}$ The reasons for China's export success and apparent cost advantage in solar equipment are beyond the scope of this paper. ${ }^{11}$ However, extensive data collection and field research by de la Tour et al. (2011) identify the importance of international technology transfer as the driver of China's success. They argue that successful entry into each segment of PV production requires state-of-the-art production technology. Turnkey operations can be purchased in the downstream cell and module assembly segments, while equipment suppliers are scarce in the upstream segments of silicon purification and wafer production. Particularly in these more advanced segments and for continuing adaptive innovation in downstream segments, de la Tour $e t$ al.

${ }^{9}$ See Diane Cardwell, "China's Feud with West on Solar Leads to Tax," The New York Times, July 18, 2013, http://www.nytimes.com/2013/07/19/business/energy-environment/chinas-feud-with-west-on-solar-leads-totax.html.

${ }^{10}$ Ibid.

${ }^{11}$ Besides concerns about government subsidies and export pricing behavior, observers often point to scale economies due to the large size of almost all aspects of PV manufacturing in China. 
(2011) highlight the importance of skills and indigenous adaptation as key the sector's development.

During this development process, intellectual returnees played a crucial role in mastering the technology and techniques needed to produce for export. Pioneers in the industry are the well known “three returnees of China’s photovoltaic,” Huaijin Yang, Zhengrong Shi, and Jianhua Zhao. These three men, originally from Jiangsu province, studied photovoltaic technology in Australia in the 1990s, and then returned to China with advanced technology and foreign capital to start firms using China's relatively low-wage skilled labor force.

Besides the famous "three returnees," there are hundreds of other returnees in China's PV sector. The importance of returnees to the industry is a central finding from field interviews carried out by Luo and Yu (2012) and by de la Tour et al. (2011). These sources suggest that China benefited not only from the return of foreign trained pioneers but also a continuing flow of talent back to the Chinese PV industry. Exact counts are not available, but industry sources report most large firms engage in aggressive recruiting of ex-pat executives with overseas training.

\section{A patent explosion in Chinese photovoltaics}

Due partly by increased official attention to patenting, over the past decade there has been a Chinese patent "explosion" (Hu and Jefferson, 2009). Analysis by Eberhardt, Helmers, and $\mathrm{Yu}$ (2012) find that the number of domestic filings with the Chinese patent office increased at an average annual rate of $35 \%$ during the period 1999-2006. However, their examination of domestic and international patent applications by manufacturing firms registered in China indicates that an overwhelming share were from a handful of companies in the ICT equipment 
sector, especially for those also filed with the U. S. Patent Office. ${ }^{12}$ Moreover, they find that most innovation is done by large, relatively young firms that are more R\&D-intensive and export oriented than their peers.

Similarly, de la Tour et al. (2011) document an increase in both China's solar photovoltaic patenting activity and an increase in China's share of global PV patents. Our work builds on theirs by examining the characteristics of the Chinese firms acquiring these patents. ${ }^{13}$ To document these firms' innovative activity, we search and extract all patents records for Chinese PV firms filed in China, using records of the State Intellectual Property Office (SIPO), and with international patent offices, using records from the Delphion patent database. ${ }^{14}$ As further checks to ensure completeness, we also search for information on Chinese patents using the China National Knowledge Infrastructure (CNKI). ${ }^{15}$

These methods yield a total of 3508 patent applications from 290 of the 806 Chinese firms active in the industry through 2011. The number of patents assigned to these firms increased from 14 in 2000 to 973 in 2010, implying an annual growth rate of $68 \%$. Figure 2 shows the distribution of patent counts among those firms with patents. Compared to other industries in China (Eberhardt et al., 2012), patenting is more widespread in the PV industry. The average patent count among all firms is 4.35 , with an average of 12.1 among those with one

\footnotetext{
${ }^{12}$ Because of the costs of filing abroad, along with a one-year waiting period that gives inventors additional time to gauge their invention's value, only the most valuable inventions are filed in multiple countries. Because of this, researchers such as Lanjouw and Schankerman (2004) have used data on patent families as proxies for the quality of individual patents. Lanjouw and Mody (1996) use such data to show that environmental technologies patented by developed country firms are more general than similar inventions from developing countries, as the developed country inventions are protected in more countries.

${ }^{13}$ As explained in more detail in section 4, we use China's Annual Survey of Industrial Firms to identify all firms operating in any segment of the PV supply chain.

${ }_{15}^{14}$ Delphion provides worldwide detailed worldwide patent information at http://www.delphion.com/.

${ }^{15}$ A sub-dataset of CNKI provides all updated patents information of SIPO at http://dbpub.cnki.net/Grid2008/Dbpub/Brief.aspx?ID=SCPD\&subBase=all.
} 
or more patents. Thus, while many firms have patents, most firms have only a few.

Detailed scrutiny of the 3508 patent records suggests that much of this innovative activity represents the "incremental innovation" highlighted by Puga and Trefler (2010) as necessary to move production of new technologies to developing countries. First, we reviewed each patent to identify whether it represented a process or product innovation. Most patents represent process innovations: improved devices, tools, or methods that enhance production efficiency or product quality; only a few patents represent product innovation, in which a new higher quality final product is patented. The share of product innovation patents rose in recent years.

Secondly, we gain additional information on the quality of Chinese PV innovation can be gained by examining the type of patent protection sought. Not all patenting activity signals the same level of innovation and Chinese patent documents contain details that make it possible to sort them into categories reflecting innovation quality. Specifically, Chinese patent law permits three types of patents - invention, utility, and design - and the type is listed in the patent record. Invention patents refer to new technical solutions relating to a product or process. They provide 20 years of protection and are analogous to patents in industrialized economies. Utility patents refer to minor improvements to existing technology. They provide only 10 years of protection and apply to any new technical solution relating to the shape or structure of a product. Design patents cover the aesthetic design of a product and also provide just 10 years of protection. ${ }^{16}$

As illustrated in Figure 3, about two-thirds of patent applications from Chinese PV firms represent utility and design innovations. While only about one-third of patents are invention patents, the number of these more valuable innovations increases steadily over the decade.

\footnotetext{
${ }^{16}$ Descriptions of the various patent types come from the State Intellectual Property Office of P.R.C, http://www.sipo.gov.cn/zsjz/zhzs/200804/t20080418_383771.html, and the Embassy of United States, http://beijing.usembassy-china.org.cn/iprpatent.html.
} 
These trends are consistent with an industry that used existing technology from foreign countries and initially directed research efforts mainly to adaptation and "minor" innovation rather than basic research. As the industry expanded, however, it seems that more effort was directed to fundamental research resulting in more invention patents.

Table 1 provides more detail on the top patenting PV firms in China: Suntech, Trina, Shanghai Solar, CEEG, and Yingli. These firms are domestic, either private or state-owned enterprises. ${ }^{17}$ In addition to their patent counts, the table shows that with the notable exception of Suntech, most firms have more utility and design patents than invention patents and hold few international patents. Finally, based on our reading of individual patents, columns 5 and 6 of Table 1 show the share of each firm's patents that are product versus process innovations. Unlike the broader sample of firms, for these top innovators, a majority of their patents represent new products rather than improved processes.

\section{Research design: intellectual returnees and innovation capacity}

We use the patent data described in section 2 to investigate the role of intellectual returnees on innovation. Our basic approach is to regress a firm's patent count on an indicator for the presence of an intellectual returnee among a firm's leadership. We control for a variety of other factors that determine the firm's innovative activity. We identify the effects of international experience using both differences between and within firms, as we discuss in greater detail below.

\footnotetext{
${ }^{17}$ Of the top nine PV companies in China in 2008 and 2009, de la Tour et al. (2011) find that only three have investment links with foreign companies and these are late arrivals, following the Chinese pioneers.
} 


\section{Patents counts as an indicator of technology innovation}

We use patents as a measure of each firm's innovation efforts. Patents provide a temporary legal monopoly to use an innovation in a specific market. In contrast to data on R\&D spending, which has only limited availability and is subject to numerous measurement problems, patents are publicly available documents, with a long history even in some developing countries (Nagaoka, Motohashi, and Goto, 2010). While patents are an output of the innovation process, economists have found that patents provide a good indicator of innovation activity (see, e.g., Griliches 1990). Moreover, due to the detail available on patent documents, patents are widely used in studies of environmental innovation (see Popp et al. 2010 for a review).

Nonetheless, when working with patent data, it is important to be aware of their limitations. The existing literature on the benefits and drawbacks of using patent data is quite large. ${ }^{18}$ While the tendency to patent varies across industry and by country, focusing on a single industry in a single country mitigates many of these concerns in our study. Also, as noted earlier, Chinese patent data enable us to address differences in the quality of patented inventions, using the categories of invention, utility, and design described in section 2 .

\section{Determinants of a firm's technology innovation}

Many internal and external factors determine a firm's technology innovation activities. Our study focuses on the role of international technology transfers resulting from international personnel movement. Returnees may be an important technology transfer channel, but their impact is not well studied because international personnel movement is typically conceived as a "brain drain" through which talent is transferred from developing nations to the developed world

\footnotetext{
${ }^{18}$ Griliches (1990) provides a useful survey.
} 
(Fagerberg et al., 2010). Part of the explanation for this gap in the literature may also be the difficulty of obtaining data on returning intellectuals and their innovative activities. With the recent emergence of indigenous innovation and large existing stock of overseas talent, however, China presents a unique opportunity to study the possible impact of intellectual returnees. Returned talent can improve a firm's innovative performance through a variety of channels. First, intellectual returnees represent a transfer of technology through human capital (Kapur and McHale, 2005). They generally have better professional training than domestic peers and, thus, provide a new source of knowledge to the enterprise. Some returnees are facile with advanced technologies from employment in developed country firms and may even hold patents pertaining to these technologies. Secondly, returnees often are recruited back to China at salaries higher than those paid to domestic workers and are placed in leadership roles within the firm. A leadership position may give an intellectual returnee the platform by which to influence the firm's innovative and patenting activity. For these reasons, we expect that the presence of intellectual returnees in a leadership position to raise a firm's patenting activity. ${ }^{19}$

To ensure that we isolate the effect of returnees within the firm, we must control for other factors that also influence its patenting behavior. One channel may be through talent located in neighboring firms that raises a firm's innovative potential through formal or informal interactions or even personnel movement among firms (Zucker and Darby, 2007; Filatotchev et al. (2011)). Therefore, in testing for a positive relationship between a firm's returnees and its patenting activity, we control for the presence of returnees as leaders of neighboring firms.

Additional spillovers may come from external scale economies or co-location near major

\footnotetext{
${ }^{19}$ While we focus on returnees and innovative performance, some researchers argue that returnees have disadvantages in that they lack local connections and local knowledge and that these disadvantages lead to poorer performance by firms started by returnee entrepreneurs (see Li, et al. 2012 for discussion).
} 
universities. External economies would be evidenced by industry agglomeration, which may affect firms' innovation by facilitating knowledge spillovers, through input-output linkage and by labor market sharing (Ellison, Glaeser, and Kerr, 2010). Major universities or research institutes can also be the source of innovative capacity, especially where enterprise-university linkages are strong (Edquist, 2004). We create measures of both industry agglomeration and proximity to research centers to control for these factors.

The literature on firm-level innovation suggests other channels of international technology transfer, such as international trade and FDI, that also contribute to firms' technology innovation (Lin and Zhang, 2005; Keller, 2010). While there is very little foreign investment in the PV sector, there are significant export flows and keeping up with competition in export markets may induce more innovative activity. Therefore, we also control for firm export intensity in our empirical implementation.

The literature also suggests several firm characteristics that are important determinants of innovative performance (Cohen (2010) provides a review). Examples include firm size, age, and market share. We include these as controls in the model that follows. Lastly, we include year fixed effects to control for patenting shocks common across firms in a given year, such as those due to changes in government policy, bank lending behavior, or the business cycle.

\section{Empirical implementation}

Our data set, described in detail in section 4, is an unbalanced panel of 806 firms over the time period 1998-2008. Our dependent variable is the number of patent applications filed by firm $i$ in year $t$, where $t$ is the application year of the patent. The basic empirical model is:

$$
\begin{gathered}
\text { Patent }_{i, t}= \\
f_{\text {IntlExper_Leader }}, \text { IntlExper_Exec }_{i t}, \ln \left(\text { IntlExper_Cluster }_{i t}\right), \\
\left.\ln \left(\text { IndustryCluster }_{i, t}\right), \ln \left(\text { UnivDist }_{i, t}\right), \mathrm{X}_{\mathrm{i}, \mathrm{t}}, \text { year }_{\mathrm{t}}\right)
\end{gathered}
$$


All continuous variables are included in logarithmic form when we estimate model (1) so that we can interpret coefficients as elasticities.

We include two indicators of the international experience of a firm's leaders. The first indicator, IntlExper_Leader $r_{i t}$ is an indicator for whether or not the firm's chief executive officer (CEO) or chairman of the board (posts usually held by the same person but not always) has international experience. IntlExper_Exec $i t$ is a dummy variable equal to one if one or more members of the firm's top management team have international experience. Depending on each individual company's organizational structure, top management may include the chief operating officer, chief technical officer, and chief science officer. International experience is defined as a certificated overseas education or foreign working experience. The most common international experience is completion of a degree from a foreign university, accounting for $80 \%$ of international experiences.

To investigate whether spillovers from the presence of returnees in neighboring firms matter in the PV industry, we create a firm-level measure of proximity to firms led by intellectual returnees. This variable, IntlExper_Cluster $i$, sums over the international experience of all other firms in year $t$, placing more weight on the international experience of nearby firms using the formula:

$$
\text { IntlExper_Cluster }_{i t}=\sum_{j \neq i} \frac{I_{j, t}}{d_{i, j}}
$$

Here, $I_{j, t}$ is a dummy variable equal to one if firm $j$ 's leader in year $t$ has international experience, and $d_{i, j}$ represents the distance between firms $i$ and $j$. We measure the distance 
between firms using county centroids. ${ }^{20}$

The inclusion of IndustryCluster ${ }_{i, t}$ tests for the effects of industry agglomeration. We measure industry clustering as the sum of other PV firms' output discounted by distance.

Defining $v_{j, t}$ as output for firm $i$ in year $t$ and $d_{i, j}$ as the distance between firms $i$ and $j$, we calculate industry cluster as:

$$
\text { IndustryCluster }_{i t}=\sum_{j \neq i} \frac{v_{j, t}}{d_{i, j}} .
$$

We use UnivDist $t_{i, t}$, to examine the potential benefits of locating near a research university. This variable measures the distance from firm $i$ to the nearest top university (or public research institute), defined as:

$$
\text { UnivDist }_{i, t}=\operatorname{Min}\left\{D_{i, u}, u=1, \ldots, 25\right\} \text {. }
$$

Here $D_{i, u}$ is the distance between firm $i$ and each of the top 25 universities in China, $u .^{21}$

$\mathrm{X}_{\mathrm{i}, \mathrm{t}}$ is a matrix of firm characteristics used as control variables. Our controls for firm characteristics include a measure of market power, defined as the share for firm $i$ in year $t$ of total PV industry sales, the export share of total sales for firm $i$ in year $t$, the age of each firm at time $t$, and the size of the firm measured as the number of employees.

We also include dummy variables indicating the nature of firm $i$ 's production: upstream (silicon purification), midstream (silicon ingot/wafer/cell), downstream (panels), or

\footnotetext{
${ }^{20}$ Since we know the county is which each firm is located, we calculate, the distance between firms in the
} same county using the common formula $\left(\frac{2}{3} \sqrt{\text { area } / \pi}\right)$, where area refers to the county's area.

${ }^{21}$ The top 25 universities and public research institutes in China are as follows: Tsinghua University, Nanjing University, Peking University, Shanghai Jiao Tong University, University of Science and Technology of China, Zhejiang University, Huazhong University of Science and Technology, Shandong University, Sichuan University, Sun Yat-sen University, Beijing University of Aeronautics and Astronautics, Dalian University of Technology, Harbin Institute of Technology, Jilin University, Southeast University, Wuhan University, Xian Jiao Tong University; and three institutes of China Academy School. University rankings are taken from http://www.shanghairanking.com/Country2011Main.jsp?param=China. 
comprehensive firms that are fully or partially integrated, producing some upstream and downstream products. While patents come from all types of firms, upstream production processes are generally more technological sophisticated, but smaller adaptive innovations are more easily produced in the downstream segment. We control for ownership with a series of dummy variables for ownership type: state, foreign, HMT (Hong Kong, Macau and Taiwan), collective, or private enterprise. Lastly, we include year dummies to control for changes over time affecting the entire industry, such as changes in environmental or patent policy.

\section{Data on Firm Characteristics, Patent Applications, and Leadership Experience}

Our research design requires the combination of firm-level data, which allow us to identify PV firms and their characteristics, with patents record for these firms over the period 1998 to 2008 . It also requires us to collect information on the identity of each firm's top management teams and whether or not they have relevant international experience. Table 2 provides summary statistics of the variables used in our regression analysis.

\section{Photovoltaic firm characteristics}

We identify photovoltaic firms from 1998 to 2008 using the Annual Survey of Industrial Production (ASIP) provided by China's National Bureau of Statistics. From this source, we obtain information on a total of 806 unique firms listing a PV product among their top three activities. The ASIP is a universal database covering all major industrial firms, including all state owned enterprises and non-state firms with annual turnover above 5 million RMB (about US $\$ 800,000$ in sales). This census provides basic information such as corporate identity, location, establishing year, and operating information such as output value, sales, intermediate input, value added and tax, employment, assets and liabilities, and other financial data. 
Photovoltaics is an emerging technology and there are no unique industry code specifying PV firms. Fortunately, the ASIP records each firm's main products, which we use both to identify firms operating in the industry and also to further categorize them into their location along the PV supply chain: upstream purification of silicon, midstream production of ingot and wafer and the creation of solar cells, and downstream industry assembly of solar panels. Some firms are vertically integrated and we code these firms separately. To ensure a complete list of firms, we scrutinize each firm's recorded products in each year it appears in the ASIP. There is entry of some firms into the industry from other sectors of the economy. Additionally, we crossreference our list with the solar company directory provided by ENF Solar, which is considered a comprehensive list of suppliers used by international purchasers of PV products. $^{22}$

\section{Patent application records and matching}

Linking firm data and to patent records is challenging because firm names and locations obtained from the ASIP are recorded in Chinese while international patent information available from Delphion is in English. To assist, we make use of another dataset, QIN, a Chinese enterprises financial database. ${ }^{23}$ We use QIN's listing of firms by both their Chinese and English names to obtain English names for those firms we have identified through the ASIP. Through this procedure, we are able to find patent information on about one third of the initial 806 firms.

About two-thirds of the initially identified PV firms are not present in QIN. For these firms, we use the following approaches to get patents records from Delphion. First, we use the firms' Chinese names to search patent record in CNKI, which contains patent records in SIPO. Secondly, we use the SIPO patent information (e.g. Publication Number) to locate the same

${ }^{22}$ ENF website: http://www.enf.cn/.

${ }^{23} \mathrm{QIN}$ is a data product of Bureau van Dijk, which provide information on companies around the world. The website is as follows: https://qin.bvdep.com. 
patent record in Delphion, and the latter record typically also contains the firm's English name, from which we can obtain the firm's complete patents records in Delphion. Third, in those few cases where Delphion patent records don't contain the firm's English name, we use company websites to identify English names. Based on these procedures, we identified patents records for all 806 firms.

\section{Firm leaders' international experience record}

Obtaining biographical information on each firm's leadership also requires painstaking search procedures. First, we identify each firm's top management team, including the chairman of the board, chief executive officer, chief operating officer, company president, chief technology officer, and chief science officer, in each year. ${ }^{24}$ For each executive, we search for a detailed biography providing information on tertiary education and industry experience. Key sources of information are each company's own official website and public online references to the company and its leaders, such as online newspapers, magazines, and industry publications. ${ }^{25}$ Through these procedures, we confirmed biographical information for the leaders of 472 of the 806 PV firms we initially identified. Firms with available information include the largest firms and together account for more than $80 \%$ of the output value of all PV firms combined. We were unable to confirm biographical information for the leadership of the 334 remaining and mainly small producers initially identified. We handle this situation in two ways econometrically. In

\footnotetext{
${ }^{24}$ Lu et al. focus on the firm's top management team, as we do here, in their study of returnees and the firm's ability to export to multiple markets.

${ }^{25}$ To obtain information of the firm's leader (founder or CEO) and the management team (executives other than CEO), we search information from the firms' website and online source. First, we check the firm's official website, where some firms provide official biographies for the leader and management team. Second, if we cannot find the information from the official website, we use internet search engines to find information on the international experience of the firm's leader and management team. Specifically, we use "Google," the largest search engine in the world; and "Baidu," the largest search engine in Chinese.
} 
our main regressions, we group those firms with missing leadership information with those confirmed as "no executives have international experience." In separate runs (unreported, but available upon request), we omit all firms with missing information from our sample and we find no qualitative differences in our regression results.

Among the 472 firms for which we have confirmed information, 115 have leaders with international experience, accounting for nearly $25 \%$ of firms with available information. We found 51 firms with a chairman or CEO who has international experience and 96 firms with similarly experienced other top management. Among those with international experience, $80 \%$ have overseas educational experience and many of them have Ph.D. degrees. The remainder, 351 of the 472 firms, did not have a leader or executives with international experience.

\section{Empirical results and discussion}

Our data set contains an unbalanced panel of 806 firms over the time period 1998-2008. ${ }^{26}$ Because the dependent variable is a count of patent applications by firm and year, we use count data panel regression techniques. We present results from both Poisson and Negative Binomial fixed effects regression models (Cameron and Trivedi, 2005; Hilbe, 2011). Below we discuss the advantages and disadvantages of each technique.

We can identify the effects of international experience using both differences between and within firms. In our data, much of the variation in leader's international experience occurs across firms. However, while between-firm variation provides more abundant information on

\footnotetext{
${ }^{26}$ While we have 1810 potential firm/year observations, fixed effect regressions will drop all firms that never patent in any year, as the fixed effect perfectly explains their patenting behavior. This leaves us with 445 observations from 106 unique firms for the fixed effect regressions.
} 
the effects of international leadership, relying on this source of variation alone risks endogeneity bias. A central concern is reverse causation: a firm that has private information about the value of its own R\&D may seek out a leader with international experience for reasons unrelated to patenting. If this channel of influence exists, estimation of (1) with a cross-section may lead to the spurious conclusion that international experience spurs patenting rather than the other way around. Within a short time frame, a firm's R\&D productivity is unlikely to change significantly, so a method of reducing the possibility of endogeneity bias is the use of firm fixed effects in our estimation procedure. Another approach is to control for firms' R\&D expenditures, although this approach cannot capture the quality of a firm's R\&D activities. We use both approaches in our empirics.

The first model we estimate is the negative binomial model, a method often used with overdispersed count data. Our dependent variable, firm-level patent counts, is overdispersed in the sense that the variance in the data is greater than the mean. Our concern about endogeneity leads us to estimate a negative binomial fixed effects (NBFE) regression, which is unusual in that it provides coefficient estimates for time-invariant variables. In our data, only eight of those firms with leaders having international experience undergo a change in this variable (e.g. bringing on a new leader who has international experience). Thus, the NBFE model allows us to better estimate the effect of international experience, as it draws on both within and across firm variation in a fixed effect setting. It also allows us to estimate the effects of time-invariant variables, such as firm ownership type, because NBFE estimation using conditional maximum likelihood allows estimation of firm-specific intercepts. However, the NBFE model has the weakness that it does not perfectly control for omitted firm time-invariant characteristics (Allison and Waterman, 2002; Paulo, 2008). 
In contrast, a Poisson fixed effects (PFE) model allows us to better control for any unobserved time-invariant firm characteristics that may affect firm-level innovation. While the Poisson model assumes that the mean and variance of the data are the same, it provides consistent estimates even if the data are overdispersed. Robust standard errors can then be used to adjust for overdispersion (Cameron and Trivedi 2005). Thus, the PFE model provides consistent results even if there are unobserved firm characteristics that bias the NBFE results, making it better suited for a causal argument. However, this model enables us to identify the effects of international experience only by the outcomes for those few firms switching status. Given these tradeoffs, we present both the NBFE and PFE results.

\section{Intellectual returnees and technology innovation}

Our results suggest that intellectual returnees both improve a firm’s technology innovation capacity and provide spillover effects to neighboring firms and, thus, are an effective channel for technology transfer. Looking first at Table 3, we see that firms whose leader has international experience have between $138 \%$ (NBFE - column 1) and 379\% (PFE - column 2) more patents than other firms. Similarly, having an executive board member with international experience increases patenting by $89 \%$ (NBFE) to $165 \%$ (PFE). These coefficients are all precisely estimated.

Recall that the NBFE estimation does not condition on unobserved fixed effects, so it identifies the effect of experience from both differences between and within firms. However, the results may be biased if, for example, a firm that has private information about the value of its own R\&D seeks out a leader with international experience. In this case, we would expect any such bias to be positive - e.g. more innovative firms, who are likely to patent more frequently anyway, will be more likely to seek out those with international experience. In contrast, the PFE 
controls for such unobserved firm characteristics. Nonetheless, the PFE effect of leadership is higher than that estimated using the NBFE model, suggesting that this sort of bias may not be a concern. We emphasize, however, that since our sample only allows us to identify the leadership effect by changes at a few firms, a priority for future research should be replication of our results in a broader sample. However, given the consistency across the two methods, we believe that the results provide strong evidence that returnees play an important role in innovation.

Clustering of PV firms is common and interactions among PV firms have been identified as a notable channel for technology transfer (de la Tour et al., 2011). Examples of these interactions include input-output linkages, technology cooperation, labor market sharing, and personal communication between firm leaders. Our fixed effects results provide evidence that these clusters are not only important, but that they are an important channel of spillover benefits from international experience. As shown in column 2 of Table 3, the estimated coefficient for our measure of returnee clustering is positive and statistically significant, with an elasticity of 0.876, suggesting that the benefits of returnees' international experience are shared among neighboring firms.

The significant effect of international experience remains robust when separating the results by patent type in Table 4 . Table 4 presents separate results for invention patents, utility and design patents, and process patents. Process patents are a subset of both invention and design patents that protect innovations designed to improve the production process, rather than advancements in the solar cells themselves. The international experience of a firm's leader remains large and significant across all three patent types and across both the NBFE and PFE models. Interestingly, the international experience of executive board members is important for utility and design patents and process patents, but not for the more significant invention patents. 
These more minor innovations typically represent adaptive innovation based on current technology and are easier to achieve while still improving product quality or reducing cost. In contrast, firms whose leaders have international experience are also more likely to do major innovations, as shown by their increased likelihood of receiving invention patents.

\section{$R \& D$ and patenting activity}

Table 5 provides descriptive statistics on the level of R\&D spending by firms with and without international experience. These data are only available for three years in our sample: 2005-2007. However, they provide some evidence that firms with internationally experienced leaders are more active researchers. Such firms do more total $R \& D$ and spend more on $R \& D$ per worker than do other firms.

Table 6 considers whether international returnees place more value on patent protection than other firm leaders. We address this by including firm R\&D spending as an explanatory variable. These results depend on a smaller sample, given the limited availability of the firmlevel R\&D data.

Column (1) of Table 6 presents results from a Poisson fixed effects regression. The interpretation of the regression including R\&D is different from those previously shown. When $\mathrm{R} \& \mathrm{D}$ is included, the regression estimates a patent production function - that is, how additional research inputs translate into research outputs. Thus, the large positive coefficients in column (1) do not tell us that firms with international experience are more innovative. Rather, they tell us that, conditional on levels of R\&D spending (e.g. research inputs), firms with international experience obtain more patents. These returnees in general are more familiar with technology frontiers, and they may as well be more aware of the importance of intellectual rights protection given by patenting. 
One troubling aspect of the results in column (1) is the insignificant coefficient on R\&D. This result is inconsistent with other recent studies examining R\&D and patenting in China, such as Eberhardt et al. (2012) and $\mathrm{Hu}$ and Jefferson (2009). A complication is that the fixed effects model can only be estimated on firms that patent at least once during the 2005-07 sample period, resulting in just 155 observations. Column (2) addresses this by using a random effects model. This expands the sample size to 705, but has the drawback that the estimates are not consistent if the unobserved individual random effects are correlated with the explanatory variables. Nonetheless, given small sample size issues that arise when working with data from hightechnology firms, it is not uncommon to include random effects results when estimating patent production functions (see, for example, Eberhardt et al. 2011, Hu and Jefferson 2009, and Huang and $\mathrm{Wu} 2012$ ).

The random effects model results allows us to verify the importance of $R \& D$, but coefficients on leader experience should be interpreted with caution, given potential unobserved effects that could determine both international experience and patenting. Column (2) shows that, as expected, firms doing more R\&D are more likely to patent, with an elasticity of 0.057 . Finally, to ascertain the role of the changing sample size, column (3) reruns the random effects regression on just those 155 observations including firms that patent at least once from 2005-07. Once again the effect of R\&D is insignificant and nearly 0 . Thus, the significant coefficient found in column (2) comes not from differences between the random effects and fixed effects model, but because of differences between those firms that do or do not patent. However, the coefficients on international experience are lower in both random effects models than in the fixed effects model, suggesting that unobserved characteristics of firms are important, verifying the importance of using fixed effects to estimate the effects of international experience on patenting. 


\section{Other determinants of firm innovation}

As noted in section 5.1, industry agglomeration provides an important channel for spillover benefits from international experience. Therefore, we also include a direct measure of industry clusters to see if agglomeration benefits, such as input-output linkage, labor market sharing and knowledge spillover, enhance technology innovation. The evidence for these benefits is limited; the coefficient is only significant in the PFE model and only at the ten percent level. In Table 4, we see that, even at the 10 percent level, industry agglomeration is important only for utility \& design and process patents. Thus, general agglomeration effects appear unimportant for more significant innovations. Similarly, our NBFE models include controls for geographic proximity to a top university. This location characteristic also has no additional impact on patent levels.

International trade is usually regarded as an important channel of international technology transfer, both through the importation of advanced capital equipment and through learning by exporting. To investigate the learning by exporting channel, the regressions in both Tables 3 and 4 include controls for firm export intensity. Domestic firms may gain access to foreign technology through exporting, or may be pressured by competition to improve products for export markets. While both can help raise innovation performance (Clerides and Saul et al., 1998; Bernard and Jensen, 1999), we find no evidence of a link between patenting and export intensity for Chinese PV firms.

\section{Concluding remarks}

The rapid growth of China's PV industry has had a profound effect on the global solar equipment market. Recent case studies illustrate how indigenous Chinese innovation facilitated 
growth in the industry and adapted advanced production methods to leverage China's lower labor costs. While previous studies suggest an important role for intellectual returnees in fostering this innovation, few studies have marshalled sufficient data to directly relate innovative activity to the presence of overseas-trained personnel in a firm's top management team.

Our analysis investigates the patenting history of 806 Chinese solar photovoltaic firms from 1998-2008. We show that firms whose leaders have international experience are more likely to patent. Moreover, the benefits of intellectual returnees spill over to neighboring firms, who also see their patenting activity increase. These spillover effects are found despite the fact that we find no evidence for more general industry agglomeration effects in our sample.

As awareness of the role of returnees in indigenous innovation grows, China's immigration and overseas training policies will continue to encourage intellectual returnees. Recruiting high-skill returnees is a strategic imperative emphasized in three national middle- and long-term plans: for scientific and technological development (2006-2020), for human resources development (2010-2020), and for education reform and development (2010-2020). China's policies now include not only incentives for the return of émigrés, but also imperatives in some sectors for overseas experiences. According to China's official statistics, more than 500 thousand Chinese students returned after training abroad during 1978-2009. In the next five years, an estimated 500,000 Chinese students will be educated abroad and an estimated 300,000 will return to China (Wang and Lai et al., 2010; Li and Xu, 2011). The resulting "brain circulation" is sure to influence China's ability to compete in production of high-tech and newly emerging sectors and influence trade patterns for years to come.

The brief history of silicon solar in China suggests caution as developing countries seek technology transfer through intellectual returnees. First, the potential for trade conflict is high as 
emerging economy firms move into high-tech sectors once considered the province only of developed countries. Adaptation of advanced production processes matched with low labor and energy costs, and sometimes subsidies by eager governments, can quickly propel new producers to large global market shares. Unless global demand growth is sufficiently rapid, import surges in Western markets may trigger a cycle of trade retaliation, ignited by the levy of antidumping and countervailing duties on developing country exports.

A second caution from the history of the PV industry warns that domestic citizens may never reap the benefits of public expenditures used to lure highly skilled individuals back home. A main subsidiary of Suntech Power, one of the world's biggest solar-panel makers, declared bankruptcy in March, 2013. Its founder, Shi Zhengrong, was an overseas scientist with Australian citizenship and had several patents to his name before deciding to return to China to start a business. The city of Wuxi lured him with a $\$ 6$ million initial investment in his company that it is unlikely to recoup. ${ }^{27}$

A final caution relates to the fine line between technology transfer and intellectual property espionage. Our analysis suggests that domestic Chinese innovative activity in silicon solar is genuine, as evidenced by the granting of patents for indigenous inventions by both Chinese and international patent offices. Nevertheless, as more scientists return home with human capital acquired in technologically advanced economies, challenges grow for resolution of intellectual property conflicts within a weak global IP protection architecture.

\footnotetext{
${ }^{27}$ For further discussion of policies toward returnees and issues of technology transfer vs. espionage, see Edward Wong and Didi Kirsten Tatlow, "China Seen in Push to Gain Technology Insights," The New York Times, June 5, 2013, http://www.nytimes.com/2013/06/06/world/asia/wide-china-push-is-seen-to-obtain-industrysecrets.html.
} 


\section{References}

Allison, P. D., \& Waterman, R. P. (2002). Fixed effects negative binomial regression models. Sociological Methodology, 32, 247-265.

Amsden, A. H. (1989). Asia's next giant: South Korea and late industrialization. New York: Oxford University Press.

Bernard, A. B., \& Jensen, J. B. (1999). Exceptional exporter performance: Cause, effect, or both? Journal of International Economics, 47(1), 1-25.

Cameron, A. C., \& Trivedi, P. K. (2005). Microeconometrics: Methods and applications. New York: Cambridge University Press.

Clerides, S. K., Lach, S., \& Tybout, J. R. (1998). Is learning by exporting important? Microdynamic evidence from Colombia, Mexico, and Morocco. The Quarterly Journal of Economics, 113(3), 903-947.

Cohen, W. (2010). Fifty years of empirical studies of innovative activity and performance. In B. H. Hall, \& N. Rosenberg (Eds.), Handbook of the Economics of Innovation (Vol. 1, pp. 129-213). Oxford: Elsevier.

de la Tour, A., Glachant, M., \& Ménière, Y. (2011). Innovation and international technology transfer: The case of the Chinese photovoltaic industry. Energy Policy, 39(2), 761-770.

Deng, Z., Jean, R.-J., \& Sinkovics, R. R. (2012). Determinants of international innovation performance in Chinese manufacturing firms: An integrated perspective. Asian Business \& Management, 11(1), 31-55.

Eberhardt, M., Helmers, C., \& Yu, Z. (2012). Is the dragon learning to fly? An analysis of the Chinese patent explosion (Working Paper No. 2011-15). CSAE, University of Oxford.

Edquist, C. (2005). Systems of innovation: Perspectives and challenges. In J. Fagerberg, D. C. Mowery, \& R. R. Nelson (Eds.), The Oxford Handbook of Innovation (pp. 181-208). Oxford: Oxford University Press.

Ellison, G., Glaeser, E. L., \& Kerr, W. R. (2010). What causes industry agglomeration? Evidence from coagglomeration patterns. The American Economic Review, 100(3), 1195-1213.

European Photovoltaic Industry Association. (2011). Global market outlook for photovoltaics until 2015. Brussels: European Photovoltaic Industry Association. Retrieved from http://www.epia.org/news/publications/ 
Fagerberg, J., \& Verspagen, B. (2002). Technology-gaps, innovation-diffusion and transformation: An evolutionary interpretation. Research Policy, 31(8-9), 1291-1304.

Fagerberg, J., Srholec, M., \& Verspagen, B. (2010). Innovation and economic development. In B. H. Hall, \& N. Rosenberg (Eds.), Handbook of the Economics of Innovation (Vol. 2, pp. 822-872). Oxford: Elsevier.

Fan, C. S., Hu, Y., \& Zheng, H. (2008). A theoretical and empirical study on the impacts of FDI on indigenous innovation in China. Economic Research Journal (Chinese), 43(1), 89102.

Filatochev, I., Liu, X., Lu, J., \& Wright, M. (2011). Knowledge spillovers through human mobility across national borders: Evidence from Zhongguancun Science Park in China. Research Policy, 40(3), 453-462.

Filatotchev, I., Liu, X., Buck, T., \& Wright, M. (2009). The export orientation and export performance of high-technology SMEs in emerging markets: The effects of knowledge transfer by returnee entrepreneurs. Journal of International Business Studies, 40(6), 1005-1021.

Filatotchev, I., Liu, X., Lu, J., \& Wright, M. (2011). Knowledge spillovers through human mobility across national borders: Evidence from Zhongguancun Science Park in China. Research Policy, 40(3), 453-462.

Freeman, C., \& Louca, F. (2001). As time goes by: From the industrial revolutions to the information revolution. New York: Oxford University Press.

Freeman, C., \& Soete, L. (1997). The economics of industrial innovation. Cambridge: MIT Press.

Fu, X., \& Gong, Y. (2011). Indigenous and foreign innovation efforts and drivers of technological upgrading: Evidence from China. World Development, 39(7), 1213-1225.

$\mathrm{Fu}, \mathrm{X}$., \& Pietrobelli, C. (2011). The role of foreign technology and indigenous innovation in the emerging economies: Technological change and catching-up. World Development, 39(7), 1204-1212.

Griliches, Z. (1990). Patent statistics as economic indicators: A survey. Journal of Economic Literature, 28(4), 1661-1707.

Guimarães , P. (2008). The fixed effects negative binomial model revisited. Economics Letters, 99(1), 63-66. 
Hobday, M. (2000). East versus Southeast Asian innovation systems: Comparing OME- and TNC-led growth in electronics. In L. Kim, \& R. R. Nelson (Eds.), Technology, learning, and innovation: Experiences of newly industrializing economies (pp. 129-169). New York: Cambridge University Press.

Hongling, W., Li, D. D., \& Junxin, F. (2006). Does FDI facilitate or dampen indigenous R\&D? Economic Research Journal, 2, 44-56.

Hu, A. G., \& Jefferson, G. H. (2009). A great wall of patents: What is behind China's recent patent explosion? Journal of Development Economics, 90(1), 57-68.

Huang, C., \& Wu, Y. (2012). State-led technological development: A case of China's nanotechnology development. World Development, 40(5), 970-982.

Kapur, D., \& McHale, J. (2005). The global migration of talent: What does it mean for developing countries? Washington: The Center for Global Development.

Keller, W. (2010). International trade, foreign direct investment, and technology spillovers. In B. H. Hall, \& N. Rosenberg (Eds.), Handbook of the Economics of Innovation (Vol. 2, pp. 793-829). Oxford: Elsevier.

Lanjouw, J. O., \& Mody, A. (1996). Innovation and the international diffusion of environmentally responsive technology. Research Policy, 25, 549-571.

Lanjouw, J. O., \& Shankerman, M. (2004). The quality of ideas: Measuring innovation with multiple indicators. Economic Journal, 114(495), 441-465.

Levin, R. C., Klevorick, A. K., Nelson, R. R., \& Winter, S. G. (1987). Appropriating the returns from industrial research and development. Brookings Papers on Economic Activity, 1987(3), 783-820.

Li, H., Zhang, Y., Li, Y., Li-an, Z., \& Zhang, W. (2012). Returnees versus locals: Who perform better in China's technology entrepreneurship? Strategic Entrepreneurship Journal, 6(3), $257-272$.

Li, P., \& Xu, J. (2011). On the diffusion effect of intellectual returnees: An analysis based on regional differences and threshold characters in China. China Economics Quarterly (Chinese), 3, 935-964.

Lin, J. Y., \& Zhang, P. (2005). The advantage of latter comers, technology imports, and economic growth of developing countries. China Economic Quarterly (in Chinese), 4, 53-74. 
Liu, X., Lu, J., Filatotchev, I., Buck, T., \& Wright, M. (2010). Returnee entrepreneurs, knowledge spillovers and innovation in high-tech firms in emerging economies. Journal of International Business Studies, 41(7), 1183-1197.

Liu, X., Wang, C., \& Wei, Y. (2009). Do local manufacturing firms benefit from transactional linkages with multinational enterprises in China. Journal of International Business Studies, 40(7), 1113-1130.

Lu, J., Liu, X., Filatotchev, I., \& Wright, M. (2013). The impact of domestic diversification and top management teams on the international diversifcation of Chinese firms. International Business Review. Retrieved from http://dx.doi.org/10.1016/j.ibusrev.2013.07.002

Luo, S., \& Yu, Y. (2012). International technology transfer and indigenous innovation: Evidences from Chinese photovoltaic. World Renewable Energy Forum. Denver: American Solar Energy Society.

Ma, W., \& Glazer, E. (2013, March 20). Suntech is pushed into Chinese bankruptcy court. Wall Street Journal. Retrieved from http://online.wsj.com/article/SB10001424127887324557804578372082733827860.html

Mountford, A. (1997). Can a brain drain be good for growth in the source economy? Journal of Development Economics, 53(2), 287-303.

Nagaoka, S., Motohashi, K., \& Goto, A. (2010). Patent statistics as an innovation indicator. In B. H. Hall, \& N. Rosenberg (Eds.), Handbook of the Economics of Innovation (Vol. 2, pp. 1083-1127). Oxford: Elsevier.

Oettl, A., \& Agrawal, A. (2008). International labor mobility and knowledge flow externalities. Journal of International Business Studies, 39(8), 1242-1260.

Popp, D., Newell, R. G., \& Jaffe, A. B. (2010). Energy, the environment, and technological change. In B. H. Hall, \& N. Rosenberg (Eds.), Handbook of the Economics of Innovation (Vol. 2, pp. 873-937). Oxford: Elsevier.

Puga, D., \& Trefler, D. (2010). Wake up and smell the ginseng: International trade and the rise of incremental innovation in low-wage countries. Journal of Development Economics, 91(1), 64-76.

Smith, K. (2005). Measuring innovation. In J. Fagerberg, D. Mowery, \& R. Nelson (Eds.), The Oxford Handbook of Innovation (pp. 148-177). New York: Oxford University Press.

Song, J., Almeida, P., \& Wu, G. (2003). Learning-by-hiring: When is mobility more likely to facilitate interfirm knowledge transfer? Management Science, 49(4), 351-365. 
Veugelers, R., \& Cassiman, B. (2004). Foreign subsidiaries as a chanel of international technology diffusion: Some direct firm level evidence from Belgium. European Economic Review, 48(2), 455-476.

Wang, H., \& Lai, M. (2010). International technology transfer, heterogeneity and technology innovation in China. Management World, 12, 131-142.

Wang, H., Zweig, D., \& Lin, X. (2011). Returnee entrepreneurs: Impact on China's globalization process. Journal of Contemporary China, 20, 413-431.

Xu, X., \& Sheng, Y. (2012). Productivity spillovers from foreign direct investment: Firm-level evidence from China. World Development, 40(1), 62-74.

Zucker, L., \& Darby, M. (2007). Star scientists, innovation and regional and national immigration (Working Paper No. 13547). Cambridge: National Bureau of Economic Research. 


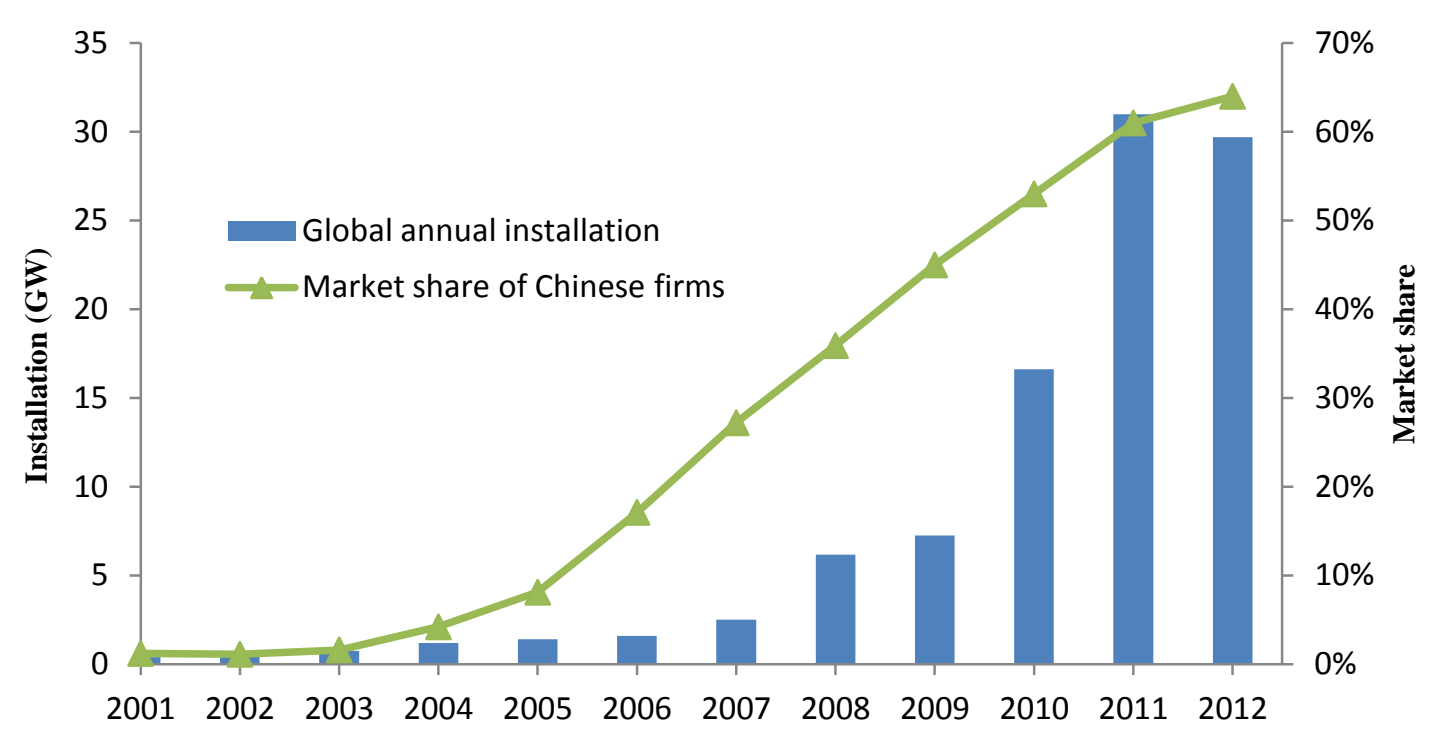

Figure 1: Global Solar Photovoltaic Installation and Chinese Firms' Market Share, 2001-

2012 Source: EPIA, 2013

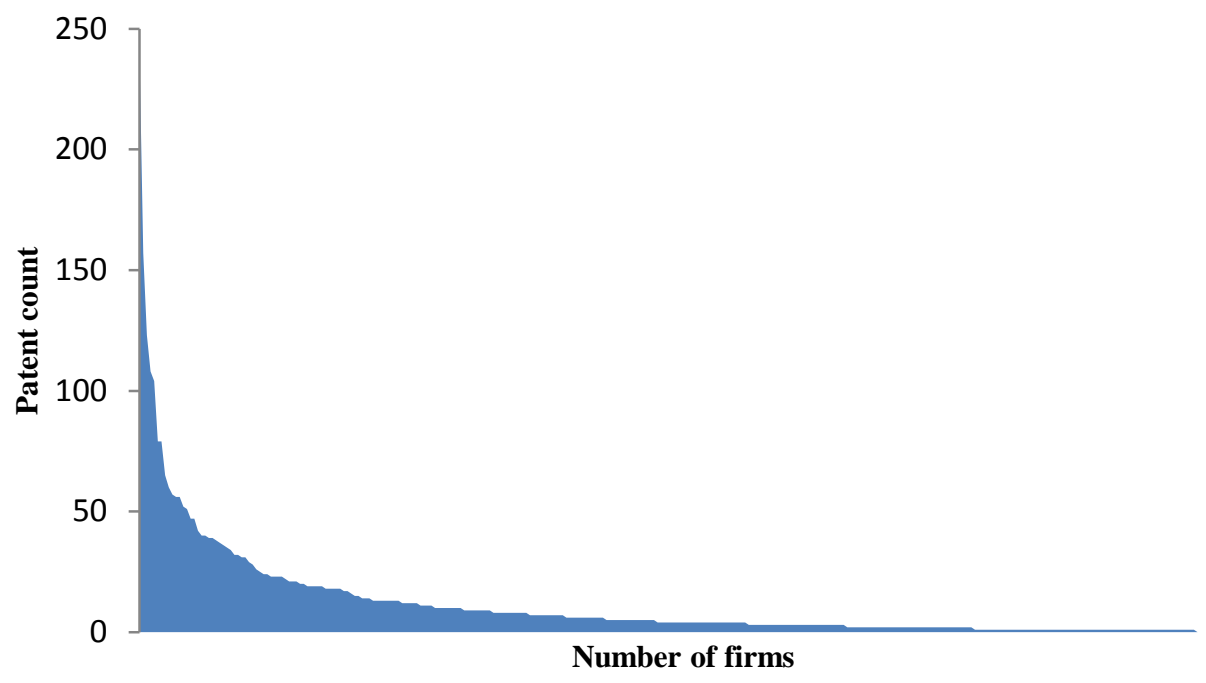

Figure 2: Chinese PV Patent Count across Firms with Patent Records, 1998-2011

Source: Delphion \& SIPO, 2012 


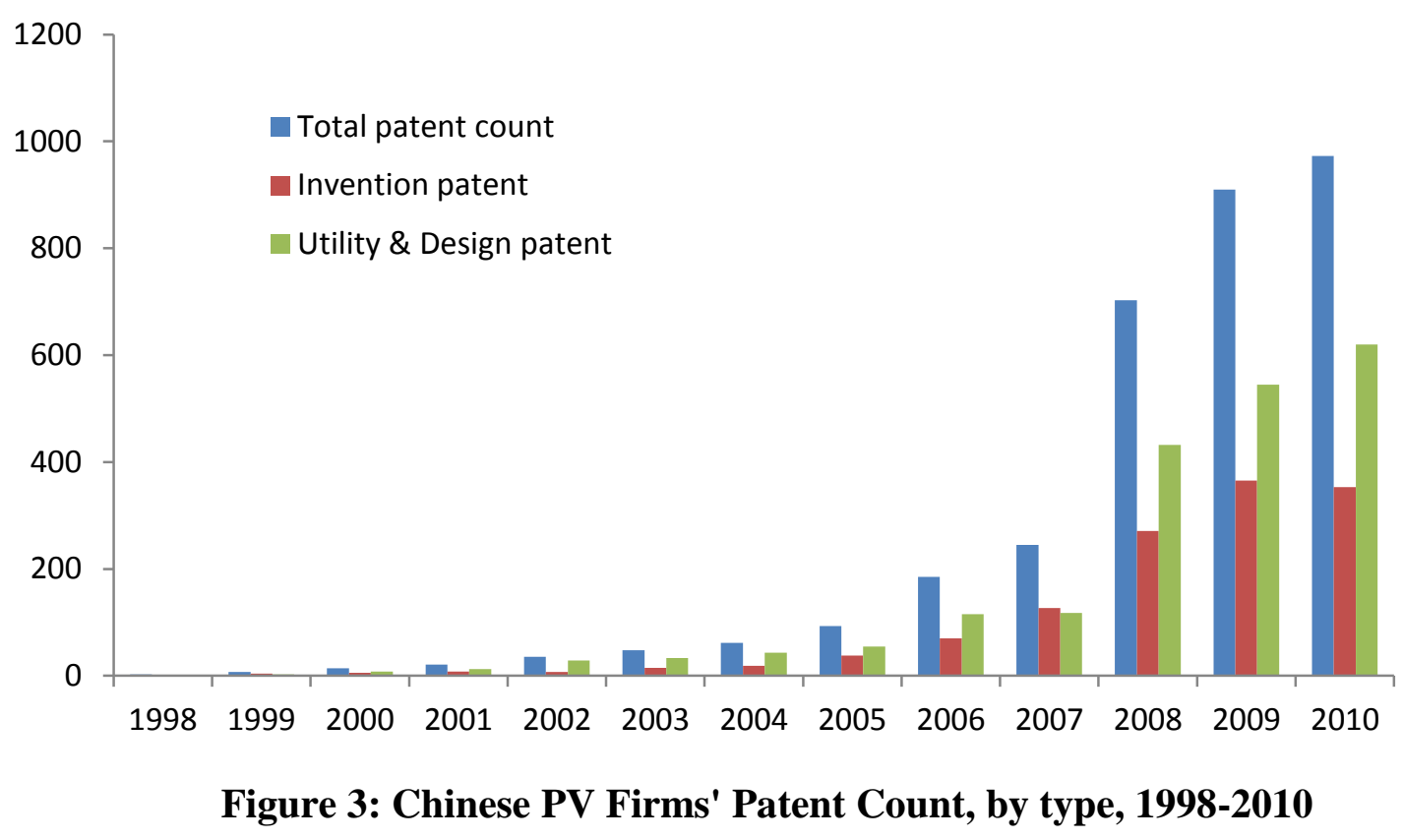

Source: Delphion \& SIPO, 2012

Table 1: Top Chinese Patenting Photovoltaic Firms

\begin{tabular}{c|c|c|c|c|c|c|c}
\hline \hline Firm & $\begin{array}{c}\text { Total } \\
\text { patents }\end{array}$ & $\begin{array}{c}\text { Invention } \\
\text { patents }\end{array}$ & $\begin{array}{c}\text { Utility \& } \\
\text { Design patents }\end{array}$ & $\begin{array}{c}\text { Product } \\
\text { technology } \\
\text { share }\end{array}$ & $\begin{array}{c}\text { Process } \\
\text { technology } \\
\text { share }\end{array}$ & $\begin{array}{c}\text { International } \\
\text { patents }\end{array}$ & $\begin{array}{c}\text { Ownership } \\
\text { type }\end{array}$ \\
\hline Suntech & 157 & 98 & 59 & $59.9 \%$ & $40.1 \%$ & 70 & Private \\
Trina & 123 & 47 & 76 & $66.7 \%$ & $33.3 \%$ & 7 & Private \\
Shanghai & 104 & 45 & 59 & $60.6 \%$ & $39.4 \%$ & 0 & State \\
Solar & 79 & 30 & 49 & $73.4 \%$ & $26.6 \%$ & 0 & State \\
CEEG & 65 & 30 & 35 & $69.2 \%$ & $30.8 \%$ & 3 & Private \\
Yingli & 65 & & & & & \\
\hline \hline
\end{tabular}

Source: Authors calculation using data from Delphion 
Table 2: Summary Statistics of Main Variables Used in Regression Analysis

\begin{tabular}{|c|c|c|c|}
\hline Variable & Definition & Mean & St. Dev. \\
\hline Patent $_{i, t}$ & Firm's annual patent application count & 0.63 & 2.98 \\
\hline IntlExper_Leader ${ }_{i t}$ & $\begin{array}{l}\text { CEO or Chairman of Board has international } \\
\text { experience or not }\end{array}$ & 0.08 & 0.27 \\
\hline IntlExper_Exec ${ }_{i t}$ & $\begin{array}{l}\text { Other members of top management team have } \\
\text { international experience or not }\end{array}$ & 0.13 & 0.34 \\
\hline IntlExper_Cluster ${ }_{i t}$ & $\begin{array}{l}\text { Proximity to firm leaders with international } \\
\text { experience, measured as the sum of the inverse } \\
\text { distance of all other firms whose leaders have } \\
\text { international experience }\end{array}$ & 0.31 & 0.46 \\
\hline IndustryCluster $_{i, t}$ & $\begin{array}{l}\text { Industry agglomeration, measured as sum of all } \\
\text { other firms' output value discounted by distance }\end{array}$ & $2.62 \times 10^{11}$ & $1.18 \times 10^{12}$ \\
\hline UnivDist $_{i, t}$ & $\begin{array}{l}\text { University closeness, measured as firm's distance } \\
\text { to the nearest top university (or public research } \\
\text { institute) }\end{array}$ & 201.26 & 277.27 \\
\hline MarketPower $_{i, t}$ & $\begin{array}{l}\text { Market power, measured as firm revenue as share } \\
\text { of all PV firm revenue }\end{array}$ & 0.006 & 0.016 \\
\hline Export $_{i, t}$ & $\begin{array}{l}\text { Export share, measured as export sales divided } \\
\text { by firm's total sales }\end{array}$ & 0.27 & 0.37 \\
\hline$R D_{i, t}$ & $\mathrm{R} \& \mathrm{D}$ expenditure, in $1000 \mathrm{RMB}$ & 1001.52 & 3554.50 \\
\hline$A g e_{i, t}$ & Firm's age & 7.24 & 10.17 \\
\hline Size $_{i, t}$ & Firm's size, measured as number of employees & 312.17 & 1166.58 \\
\hline Ownership ${ }_{i}^{+}$ & $\begin{array}{l}\text { Multiple dummy variables, denoting firm } \\
\text { registration type as State, Foreign, HMT (Hong } \\
\text { Kong, Macau and Taiwan), Collective, or Private }\end{array}$ & - & - \\
\hline FirmCategory $_{i}^{++}$ & $\begin{array}{l}\text { Multiple dummy variables, denoting firm type as } \\
\text { silicon purification, silicon ingot/wafer/cell, } \\
\text { silicon panels, comprehensive silicon solar firms, } \\
\text { non-silicon solar or other PV application }\end{array}$ & - & - \\
\hline Year $_{t}$ & Year dummy variables & - & - \\
\hline
\end{tabular}

Notes: Summary statistics are based on the PV firm's unbalanced panel between 1998 and 2008, except for R\&D expenditures, which are only available from 2005 to 2007.

${ }^{+}$Ownership contribution of the total firm-year sample is as follows, Foreign (0.133), HMT (0.104), Private (0.505), State (0.148), Collective (0.030) and Others (0.080).

${ }^{++}$Firm Category contribution of the total firm-year sample is as follows, Silicon Purification (0.065), Silicon Ingot/Wafer/Cells (0.344), Silicon Panels (0.147), Comprehensive Silicon (0.053), Non-silicon (0.023), and PV application (0.368) 
Table 3: Negative Binomial \& Poisson Fixed-Effect Estimation, Total Patent Count

\begin{tabular}{|c|c|c|}
\hline \multirow{2}{*}{$\begin{array}{c}\text { Dependent Variable } \\
\text { Estimator }\end{array}$} & \multicolumn{2}{|c|}{ Total Patent Count } \\
\hline & $\begin{array}{cl}{[1]} \\
\text { Negative Binomial FE }\end{array}$ & $\begin{array}{c}{[2]} \\
\text { Poisson FE }\end{array}$ \\
\hline IntlExper_Leader ${ }_{i t}$ & $\begin{array}{c}.384 * * * \\
0.436\end{array}$ & $\begin{array}{c}3.792 * * * \\
0.374\end{array}$ \\
\hline${ }_{\text {IntlExper_Exec }}{ }_{i t}$ & $\begin{array}{c}0.894 * * \\
0.407\end{array}$ & $\begin{array}{c}1.649 * * * \\
0.402\end{array}$ \\
\hline Ln(IntlExper_Cluster $\left.{ }_{i t}\right)$ & $\begin{array}{l}0.198 \\
0.236\end{array}$ & $\begin{array}{c}0.876^{* *} \\
0.375\end{array}$ \\
\hline Ln(IndustryCluster $\left.{ }_{i, t}\right)$ & $\begin{array}{c}-0.044 \\
0.11\end{array}$ & $\begin{array}{l}0.289 * \\
0.164\end{array}$ \\
\hline $\operatorname{Ln}\left(\operatorname{Univ}_{\mathrm{Dist}}{ }_{i, t}\right)$ & $\begin{array}{l}-0.016 \\
0.166\end{array}$ & - \\
\hline Ln(MarketPower $\left.{ }_{i, t}\right)$ & $\begin{array}{c}0.426^{* * * *} \\
0.157\end{array}$ & $\begin{array}{c}-0.357^{* *} \\
0.166\end{array}$ \\
\hline $\operatorname{Ln}\left(\operatorname{Export}_{i, t}\right)$ & $\begin{array}{c}-0.162 * * \\
0.064\end{array}$ & $\begin{array}{l}0.079 \\
0.087\end{array}$ \\
\hline $\operatorname{Ln}\left(A g e_{i, t}\right)$ & $\begin{array}{l}0.049 \\
0.131\end{array}$ & $\begin{array}{l}0.056 \\
0.239\end{array}$ \\
\hline $\operatorname{Ln}\left(\operatorname{Size}_{i, t}\right)$ & $\begin{array}{l}0.058 \\
0.153\end{array}$ & $\begin{array}{l}0.382 \\
0.246\end{array}$ \\
\hline Log-Likelihood & -337.48 & -503.61 \\
\hline Number of Observations & 445 & 445 \\
\hline
\end{tabular}

Notes: Estimation also includes year, firm ownership type, and firm category dummies.

Standard errors in parentheses. $* \mathrm{p}<0.10, * * \mathrm{p}<0.05, * * * \mathrm{p}<0.01$ 
Table 4: Negative Binomial \& Poisson Fixed-Effect Estimation, Patent Count by Type

\begin{tabular}{|c|c|c|c|c|c|c|}
\hline \multirow{2}{*}{$\begin{array}{c}\text { Dependent Variable } \\
\text { Estimator }\end{array}$} & \multicolumn{2}{|c|}{ Invention Patent } & \multicolumn{2}{|c|}{ Utility \& Design Patent } & \multicolumn{2}{|c|}{ Process Patent } \\
\hline & $\begin{array}{c}{[1]} \\
\text { NBFE }\end{array}$ & $\begin{array}{c}\text { [2] } \\
\text { Poisson } \\
\text { FE }\end{array}$ & $\begin{array}{c}{[3]} \\
\text { NBFE }\end{array}$ & $\begin{array}{c}{[4]} \\
\text { Poisson } \\
\text { FE }\end{array}$ & $\begin{array}{c}{[5]} \\
\text { NBFE }\end{array}$ & $\begin{array}{c}{[6]} \\
\text { Poisson } \\
\text { FE }\end{array}$ \\
\hline \multirow[t]{2}{*}{ IntlExper_Leader ${ }_{i t}$} & $2.162 * * *$ & $3.232 * * *$ & $1.179^{*}$ & $14.00 * * *$ & $1.446 * * *$ & $3.375^{* * *}$ \\
\hline & 0.662 & 1.072 & 0.667 & 0.983 & 0.479 & 0.378 \\
\hline \multirow[t]{2}{*}{${ }_{\text {IntlExper_Exec }}{ }_{i t}$} & 0.141 & 14.09 & $1.054 * *$ & $1.523 * * *$ & $0.986 * *$ & $1.640 * * *$ \\
\hline & 0.788 & 671.2 & 0.498 & 0.425 & 0.42 & 0.394 \\
\hline \multirow[t]{2}{*}{ Ln(IntlExper_Cluster $\left.{ }_{i t}\right)$} & 0.405 & $1.279 * * *$ & -0.133 & 0.678 & 0.156 & $0.748 * *$ \\
\hline & 0.434 & 0.403 & 0.285 & 0.477 & 0.241 & 0.369 \\
\hline \multirow[t]{2}{*}{ Ln(IndustryCluster $\left.{ }_{i, t}\right)$} & 0.063 & 0.007 & 0.040 & $0.414 *$ & -0.001 & $0.331 *$ \\
\hline & 0.142 & 0.106 & 0.130 & 0.218 & 0.110 & 0.173 \\
\hline \multirow[t]{2}{*}{$\operatorname{Ln}\left(\right.$ UnivDist $\left._{i, t}\right)$} & -0.269 & - & -0.094 & - & 0.004 & - \\
\hline & 0.295 & - & 0.22 & - & 0.171 & - \\
\hline \multirow[t]{2}{*}{ Ln( MarketPower $\left._{i, t}\right)$} & 0.258 & -0.083 & $0.320^{*}$ & $-0.445^{*}$ & $0.383 * *$ & $-0.383 * *$ \\
\hline & 0.209 & 0.150 & 0.190 & 0.233 & 0.156 & 0.177 \\
\hline \multirow[t]{2}{*}{$\operatorname{Ln}\left(\operatorname{Export}_{i, t}\right)$} & -0.034 & 0.092 & -0.054 & 0.092 & $-0.142 * *$ & 0.075 \\
\hline & 0.087 & 0.056 & 0.085 & 0.110 & 0.067 & 0.093 \\
\hline \multirow[t]{2}{*}{$\operatorname{Ln}\left(A g e_{i, t}\right)$} & -0.213 & -0.238 & 0.071 & 0.138 & 0.087 & 0.102 \\
\hline & 0.198 & 0.181 & 0.146 & 0.230 & 0.135 & 0.214 \\
\hline \multirow[t]{2}{*}{$\operatorname{Ln}\left(\operatorname{Size}_{i, t}\right)$} & 0.053 & $0.328 *$ & -0.204 & 0.296 & 0.007 & 0.346 \\
\hline & 0.208 & 0.176 & 0.205 & 0.282 & 0.156 & 0.248 \\
\hline Log-Likelihood & -187.94 & -224.54 & -232.72 & -336.69 & -316.73 & -445.37 \\
\hline Number of observations & 326 & 326 & 370 & 370 & 445 & 445 \\
\hline
\end{tabular}

Notes: Estimation also includes year, firm ownership type, and firm category dummies.

Standard errors in parentheses. $* \mathrm{p}<0.10, * * \mathrm{p}<0.05, * * * \mathrm{p}<0.01$ 
Table 5: R\&D expenditures by Chinese PV firms (in thousand RMB)

\begin{tabular}{|c|c|c|c|}
\hline & & $\begin{array}{c}\text { R\&D per } \\
\text { firm }\end{array}$ & $\begin{array}{c}\text { R\&D per } \\
\text { worker }\end{array}$ \\
\hline \multicolumn{2}{|c|}{ Among firms in PV industry } & 1001.52 & 4.21 \\
\hline \multirow{3}{*}{$\begin{array}{l}\text { Annual trends for all } \\
\text { firms }\end{array}$} & 2005 & 546.94 & 2.64 \\
\hline & 2006 & 937.11 & 4.50 \\
\hline & 2007 & 1264.47 & 4.77 \\
\hline \multirow{3}{*}{$\begin{array}{l}\text { Firms with or without } \\
\text { international experience }\end{array}$} & Leader has international experience & 1385.15 & 8.17 \\
\hline & $\begin{array}{c}\text { Executives have international } \\
\text { experience }\end{array}$ & 2070.02 & 6.14 \\
\hline & No international experience & 785.88 & 3.75 \\
\hline
\end{tabular}


Table 6: Poisson Estimation Including R\&D as a Control Variable

\begin{tabular}{|c|c|c|c|}
\hline Dependent Variables & \multicolumn{3}{|c|}{ Total Patent Count, 2005-2007 } \\
\hline Estimator & $\begin{array}{c}{[1]} \\
\text { Poisson FE } \\
\end{array}$ & $\begin{array}{c}{[2]} \\
\text { Poisson RE } \\
\end{array}$ & $\begin{array}{c}{[3]} \\
\text { Poisson RE } \\
\end{array}$ \\
\hline Samples & 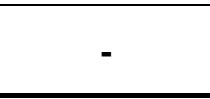 & $\begin{array}{c}\text { Using full sample } \\
(2005-2007)\end{array}$ & $\begin{array}{c}\text { Using the same } \\
\text { sample as [1] }\end{array}$ \\
\hline IntlExper_Leader $_{i t}$ & $\begin{array}{c}14.92 * * * \\
1.320\end{array}$ & $\begin{array}{l}0.528 \\
0.656\end{array}$ & $\begin{array}{l}-0.356 \\
0.415\end{array}$ \\
\hline${ }_{\text {IntlExper_Exec }}{ }_{i t}$ & $\begin{array}{c}16.46^{* * * *} \\
1.746\end{array}$ & $\begin{array}{c}2.239 * * * \\
0.501\end{array}$ & $\begin{array}{c}1.374 * * * \\
0.375\end{array}$ \\
\hline Ln(IntlExper_Cluster $\left.{ }_{i t}\right)$ & $\begin{array}{l}-0.720 \\
0.916\end{array}$ & $\begin{array}{l}0.005 \\
0.209\end{array}$ & $\begin{array}{r}-0.030 \\
0.188\end{array}$ \\
\hline Ln(IndustryCluster $\left.{ }_{i, t}\right)$ & $\begin{array}{c}0.473 * * \\
0.191\end{array}$ & $\begin{array}{c}0.380 * * * \\
0.090\end{array}$ & $\begin{array}{c}0.397 * * * \\
0.084\end{array}$ \\
\hline $\operatorname{Ln}\left(\right.$ UnivDist $\left._{i, t}\right)$ & - & $\begin{array}{l}-0.151 \\
0.140\end{array}$ & $\begin{array}{l}-0.087 \\
0.116\end{array}$ \\
\hline Ln(MarketPower $\left.{ }_{i, t}\right)$ & $\begin{array}{c}-0.902 * * * \\
0.276\end{array}$ & $\begin{array}{c}-0.772 * * * \\
0.125\end{array}$ & $\begin{array}{c}-0.630 * * * \\
0.123\end{array}$ \\
\hline $\operatorname{Ln}\left(\operatorname{Export}_{i, t}\right)$ & $\begin{array}{l}-0.058 \\
0.147\end{array}$ & $\begin{array}{r}-0.008 \\
0.058\end{array}$ & $\begin{array}{l}-0.082 \\
0.056\end{array}$ \\
\hline $\operatorname{Ln}\left(A g e_{i, t}\right)$ & $\begin{array}{l}0.397^{*} \\
0.222\end{array}$ & $\begin{array}{l}0.119 \\
0.112\end{array}$ & $\begin{array}{l}0.082 \\
0.125\end{array}$ \\
\hline $\operatorname{Ln}\left(\operatorname{Size}_{i, t}\right)$ & $\begin{array}{l}0.385 \\
0.319\end{array}$ & $\begin{array}{c}0.444 * * * \\
0.149\end{array}$ & $\begin{array}{c}0.295 * * \\
0.135\end{array}$ \\
\hline $\operatorname{Ln}\left(R D_{i, t}\right)$ & $\begin{array}{l}0.012 \\
0.070\end{array}$ & $\begin{array}{c}0.057 * * * \\
0.022\end{array}$ & $\begin{array}{l}0.011 \\
0.020\end{array}$ \\
\hline Log-Likelihood & -155.20 & -468.33 & -326.05 \\
\hline Number of observations & 155 & 705 & 155 \\
\hline
\end{tabular}

Notes: Estimation also includes year and firm ownership dummies.

Standard errors in parentheses. ${ }^{*} \mathrm{p}<0.10, * * \mathrm{p}<0.05, * * * \mathrm{p}<0.01$ 